\title{
Insectes Sociaux Best Paper 2017
}

(c) International Union for the Study of Social Insects (IUSSI) 2018

\begin{abstract}
Alejandro Farji-Brener and Mariana Tadey have received the prize for best paper published in Insectes Sociaux in 2017 for their paper "Consequences of leaf-cutting ants on plant fitness: integrating negative effects of herbivory and positive effects from soil improvement". This paper appeared in the February 2017 issue of the journal and can be found at: https://link.springer.com/article/10.1007/ s00040-016-0510-2
\end{abstract}

Farji-Brener and Tadey assessed the balance between positive impacts of leafcutter ants (acromyrmex lobicornis) on plant fitness, via soil improvement, and negative impacts, via defoliation. Their investigations were centered in the Monte Desert, an arid region stretching from subtropical to temperate interior Argentina in the rain shadow of the Andes. By comparing the fitness (flowers and fruits) of plants between areas around ant refuse dumps and control areas, as well as measuring soil nutrients in those areas, Farji-Brener and Tadey were able to test the impact of ants on nutrient flow to seven species of common desert plants. Flower abundance and fruit set did not differ substantially between refuse dump and control sites, despite the fact that $\mathrm{C}, \mathrm{N}, \mathrm{p}, \mathrm{Mg}$, and $\mathrm{K}$ were all significantly higher ( 28 times greater concentration for $\mathrm{p}$ in the refuse dump areas) than in controls. Plant species were differentially subject to defoliation by leafcutters, but there was no clear pattern of reproductive compensation for defoliation due to plant growth on refuse dumps. This study illustrates how expected outcomes from greenhouse experiments may be unsupported in field studies. Perhaps other factors, such as evolutionary accommodation by plant species that are targeted by leafcutters are important in this system. Also, the growth limitations imposed by the aridity of this environment may well translate into the plants being incapable of utilizing the enriched nutrients in the refuse dump areas. This fascinating study illustrates the importance of considering habitat dependence in making predictions about proximate responses in ecological processes (FarjiBrener and Tadey 2017).

Alejandro Farji-Brener is a Principal Investigator in CONICET, the Argentinean National Scientific and Technical Research Council, and professor from the University of Comahue in Bariloche, Argentina. His interests deal with traffic patterns of ant foragers, waste management by ants and its ecological implications, and on insect-plant interactions. He has a particular focus on leaf cutting ants in the genera Acromyrmex and Atta. Mariana Tadey is an Investigator in CONICET, and has broad interests in plant-animal interactions and arid zone ecology.

The editorial board of Insectes Sociaux selected the recipient of this award. The board consists of prominent scientists from leading universities with global representation. Insectes Sociaux publishes original scientific studies and review articles about social arthropods.

Michael Breed

Editor-in-Chief

Insectes Sociaux

\section{Reference}

Farji-Brener AG, Tadey M (2017) Consequences of leaf-cutting ants on plant fitness: integrating negative effects of herbivory and positive effects from soil improvement. Insectes Soc 64:45-54 